$\underline{\underline{\beta}}=\mathrm{E}$

\title{
Comparative efficacy of different herbal and modern anthelmintics against gastrointestinal nematodiasis in fowl
}

\author{
M. Shah Alam ${ }^{1} *, \mathrm{KJ}^{1}$ Alam, N Begum ${ }^{3}$, MR Amin ${ }^{2}$ \\ ${ }^{I}$ Department of Pathology and Parasitology, Faculty of Animal Science and Veterinary Medicine, \\ Patuakhali Science and Technology University, Babugonj, Barisal-8210 \\ ${ }^{2}$ Department of Physiology and Pharmacology, Faculty of Animal Science and Veterinary Medicine, \\ Patuakhali Science and Technology University, Babugonj, Barisal-8210 \\ ${ }^{3}$ Department of Parasitology, Faculty of Veterinary Science, Bangladesh Agricultural University, Mymensingh-2202 \\ *Corresponding author E-mail: shahbau@pstu.ac.bd
}

\begin{abstract}
The aqueous and ethanol extract of some plants and plant materials were screened for their in vitro anthelmintic effects against gastrointestinal nematodes of fowl were studied. The plant materials were extracted in distilled water (aqueous extract) and ethyl alcohol (ethanol extract). Screening of freshly prepared aqueous extract of three plant materials namely neem (Azadirachta indica), papaya (Carica papaya), korolla (Momordica charantia) and two patent drugs Eskanex ${ }^{\circledR}$ (Levamisole) and Eskapar® (Piperazine) were selected. Aqueous extracts of $25 \mathrm{mg} / \mathrm{ml}, 50 \mathrm{mg} / \mathrm{ml}$ and $100 \mathrm{mg} / \mathrm{ml}$ concentration; ethanol extracts of $10 \mathrm{mg} / \mathrm{ml}, 25 \mathrm{mg} / \mathrm{ml}$, and $50 \mathrm{mg} / \mathrm{ml}$ were used for screening. Among the selected plants and patent drugs and all three concentration of aqueous extracts papaya seed was found best at $25 \mathrm{mg} / \mathrm{ml}$ concentration $(41 \%), 50 \mathrm{mg} / \mathrm{ml}$ concentration $(74 \%)$ and $100 \mathrm{mg} / \mathrm{ml}(92 \%)$ followed by korolla $(22 \%, 70 \%$ and $90 \%$ in $25 \mathrm{mg} / \mathrm{ml}$, $50 \mathrm{mg} / \mathrm{ml}$ and $100 \mathrm{mg} / \mathrm{ml}$ concentration respectively) against adult parasite and these plants namely papaya seed showed significant efficacy against infective larvae L3. Ethanol extracts of plants also showed significant efficacy against adult gastrointestinal worms at a concentration of $50 \mathrm{mg} / \mathrm{ml}$. Among the selected plants and all three concentration of the ethanol extract revealed the highest efficacious plant $(100 \%)$ at a concentration of $50 \mathrm{mg} / \mathrm{ml}$. In all concentrations of ethanol extract papaya was observed as the best plant $(100 \%, 98 \%$ and $84 \%$ at $50 \mathrm{mg} / \mathrm{ml}, 25 \mathrm{mg} / \mathrm{ml}$ and $10 \mathrm{mg} / \mathrm{ml}$ concentration respectively) followed by korolla $(100 \%, 93 \%$ and $74 \%$ at $50 \mathrm{mg} / \mathrm{ml}, 25 \mathrm{mg} / \mathrm{ml}$ and $10 \mathrm{mg} / \mathrm{ml}$ concentration respectively) against adult whereas in case of larvae it showed significant efficacy. The present study suggests that papaya, korolla and neem are effective and can be used against the treatment of nematodiasis in fowl in alternative of patent drugs. More studies are needed to determine the active principles of pharmacological and toxicological assessment.
\end{abstract}

Keywords: Comparative Efficacy, Extract, Gastrointestinal, Herbal Anthelmintic, Nematodiasis.

\section{Introduction}

Gastro-intestinal nematodiasis is a common problem of fowls in the tropical and subtropical countries of the world. It is also a great problem of poultry population in Bangladesh. Among the nematodes, the Ascaridia galli, Heterakis gallinae, Capillaria spp infections are considered to be of great importance. It is also great problem of poultry population in Bangladesh.

A number of several anthelmintics are available in the market. Among them piperazine and levamisole are widely used for the treatment of nematodiasis in poultry. Besides anthelmintics now a days indigenous medicinal plants are also used as anthelmintic among them, whole korolla extract, neem leaves and seed extracts of Carica Papaya have bitter taste that act as patent anthelmintics. In this context, investigations on indigenous medicinal plants might contribute to develop effective but low-cost herbal anthelmintics. The "ayurvedic" and "unani" systems of medicine have used several hundreds of plants to cure many diseases in Bangladesh from time immemorial. However, these are mostly used in crude forms and their pharmacological preparations, dosages and mode of action are not based on strong scientific evidence. Until today very little works (Mostofa, 1983; Begum,
1997) have been performed in our country to investigate in vivo anthelmintic properties of medicinal plants. There is no report on in vitro anthelmintic effect of indigenous plants and modern anthelmintics against nematode infection and its larval stage of fowl in Bangladesh. For this reason, the present study has taken great impetus. This research work will provide useful information on anthelmintic properties of common medicinal plants to select the potential plants to be used against Ascaridia galli, Heterakis gallinae and Capillaria spp infection in chickens.

\section{Materials and method}

The present study on the screening of the indigenous medicinal plants for the in vitro anthelmintic activities against nematodes in chickens was conducted in the laboratory of the Department of Parasitology, Bangladesh Agricultural University (BAU), Mymensingh.

\subsection{Selection of plants used for screening}

Only three plants such as Neem, Papaya and Korolla were selected for in vitro screening to diet their effectiveness against chicken 
nematodes. Plants were matured and shrubs, herbs, tree and full of flowers, fruits and leaves free from diseases condition or other deformities.

\subsection{Collection of plants materials}

Plant and plants materials were collected from BAU campus and its surroundings rural areas. The plants and plant materials that were collected are as follows:

\subsection{The test parasites}

Gastrointestinal nematode used as parasites in this study. The most important gastro intestinal nematodes of the chicken are Ascaridia galli, Heterakis gallinae, and Capillaria spp.

\subsection{The test drugs}

Two patent drugs were used in this study. The drugs were Eskanex (Levamisole) and Eskapar (Piperazine). These drugs were used for positive control in vitro screening and also used to compare the anathematic efficacy of different plants.

\subsection{Preparation of plant dust and extract}

After collection and bring them to the laboratory, all fresh leaves seeds and bark were washed in running water and cut into small pieces. Firstly the plant materials were dried in the shade and then they were dried in the oven at $55-56^{\circ} \mathrm{c}$ to gain constant weight. Dust was prepared by pulverizing the dried leaves, seeds and barks with the help of a manual grinder, haman dista. A 25 mesh diameter sieve was used to obtain find dust and preserved them into air tight plastic container, till their use in extract preparation. Ten gram each category of dust were taken in a $500 \mathrm{ml}$ beaker and separately mixed with $100 \mathrm{ml}$ of different solvent (Distilled water, Ethanol). The mixtures was stirred for 30 minutes by magnetic stirrer $(6000 \mathrm{rpm})$ and let stand for $24 \mathrm{hrs}$. The mixture was filtered through a fine cloth and again through filter paper (whatman no. 1). The filtered materials were taken into a round bottom flask and then condensed by evaporation of solvent from filtrate in water bath at $50^{\circ} \mathrm{c}$ and $60^{\circ} \mathrm{c}$ for ethanol and water respectively. After the evaporation of solvent from filtrate, the condensed extract were preserved in tightly corked labeled bottle and stored in a refrigerator until their screening for anthelmintic property.

\subsection{Preparation of stock solution}

Stock solutions of plant extracts were prepared by diluting the condensed extracts with water. Different concentration of each category of plant extracts were prepared by dissolving them in the water prior to anthelmintic screening.

\subsection{Collection of adult's parasites, cultivation of larvae and their maintenance in the laboratory}

\subsubsection{Collection and maintenance of adult parasites}

Adult nematodes were obtained from the intestinal tracts of chicken slaughtered in the local market using method. Briefly the small and large intestines were collected and brought to laboratory. They were washed in tap water. The process was repeated for several times until the sediment becoming transparent. Then the adult gastro intestinal worms were collected with the help of a needle and placed in a Petri dish containing PBS (Phosphate Buffer Saline).Petri dish containing the worm was kept in incubator at $38^{\circ} \mathrm{C}$ until required experiment on same day.
2.7.2. In vitro cultivation and maintenance of infective larvae (L3) in the laboratory

The collected worms were washed several times with distill water or PBS. Then uteri of gravid females were dissected out, crushed gently in a Petri dish to release eggs. A known volume of PBS was added to eggs and incubated at room temperature $\left(25-30^{\circ} \mathrm{c}\right)$ for about $72 \mathrm{hrs}$ transferred to a $100 \mathrm{ml}$ beaker and incubated further until development of L3. During cultivation the culture media were monitored every morning for observing the development of larvae towards L3 stage. Sterile faecal culture (SFC) was made by obtaining five $\mathrm{gm}$ of faeces from chicken, free from nematode infection. The faeces were taken in a Petri dish, mixed with $10 \mathrm{ml}$ hot distilled water to kill nematode eggs if any. Pre counted eggs suspended in PBS were then spread over the faeces in the Petri dish. The Petri dish were covered with a lid and incubated at room temperature as mentioned earlier for the development of L3. Infected faecal culture (IFC) was prepared using faeces from naturally infected chicken. Five gram of faeces was placed in a Petridish $(12 \mathrm{~cm})$ and was moisture by adding distilled water, covered with a lid and incubated similarly as mentioned above. The L3 in both type of faecal cultures were recovered by Baermannization. After development L3 the culture media was washed several times in PBS through centrifugation at $2000 \mathrm{rpm}$ for 7 minutes and finally counted and suspended in a $100 \mathrm{ml}$ beaker. After cultivation, the infective larvae were maintained in the laboratory by incubating them $25-30^{\circ} \mathrm{c}$ and in sterile condition.

\subsection{Screening of plant extract for anthelmintic activity}

\subsubsection{In vitro screening of plant extract}

In vitro screening with pharmacological preparations (aqueous and ethanol extracts) of different plants was performed using L3 and adult gastro intestinal nematodes. The following techniques were followed for in vitro screening.

\subsubsection{In vitro screening with adult}

Screening of aqueous plant extract at various concentration level viz. $25 \mathrm{mg} / \mathrm{ml}$ and $100 \mathrm{mg} / \mathrm{ml}$ using both adults and L3 stage larva were performed. A $200 \mu \mathrm{l}$ PBS containing 25 adult worms (both male and female) was pipetted on to a Petri-dish and $800 \mu \mathrm{l}$ of aqueous extracts of each concentration was then added. Following a $3 \mathrm{hrs}$ treatment period at room temperature, the non-motile (dead) worms were counted and percentage was calculated.

\subsection{Statistical analyses}

In vitro mortality rate of nematode in different plant preparations at different time intervals were calculated in Statistical package for social science (SPSS). To identify the best plant and best preparations, percentage of mortality rate were transformed using. Then the transformed data transferred to the SPSS, 11.5 Version for t- test value.

\section{Results and discussion}

\subsection{A. In vitro screening of aqueous extract}

Freshly prepared aqueous extracts of selected indigenous plants, herbs and shrubs were screened in vitro in this study, at various concentration levels, using adult and larval stage of gastro intestinal nematode parasites of fowl. Aqueous extract of these plants showed potential in vitro activities against adult stages of parasite. Within these plants Korolla showed 90\% efficacy against adult worms, neem showed $94 \%$ and papaya showed $92 \%$ at a concentration of $100 \mathrm{mg} / \mathrm{ml}$. the efficacy of aqueous extract of these plants at a concentration level of $25 \mathrm{mg} / \mathrm{ml}$ and $50 \mathrm{mg} / \mathrm{ml}$ was much lower than that of concentration of $100 \mathrm{mg} / \mathrm{ml}$ (showed in Table 1). Two patent drugs Eskanex (levamisole) and Eskapar (piperazine) 
screened as positive control and compare with these plants were also $100 \%$ effective against adult gastro intestinal nematodes in vitro.

Table 1: Percent Non-Motile (Dead) Adult of Gastro Intestinal Nematode When Exposed To an Increasing Concentration of Aqueous Plant Extracts and Patent Drug in Vitro.

\begin{tabular}{|c|c|c|c|c|}
\hline \multirow[t]{2}{*}{$\begin{array}{ll}\text { Sl. } \\
\text { No. }\end{array}$} & Name of the plant & \multicolumn{3}{|c|}{$\begin{array}{l}\text { Percent non-motile adult in different con- } \\
\text { centration of plant extracts and patent drug }\end{array}$} \\
\hline & Korolla & $\begin{array}{l}25 \mathrm{mg} / \mathrm{ml} \\
20\end{array}$ & $\begin{array}{l}50 \mathrm{mg} / \mathrm{ml} \\
70\end{array}$ & $\begin{array}{l}100 \mathrm{mg} / \mathrm{ml} \\
90\end{array}$ \\
\hline 02 & Neem & 16 & 44 & 94 \\
\hline 03 & Papaya seed & 40 & 74 & 92 \\
\hline 04 & $\begin{array}{l}\text { Eskanex } \\
\text { (levamisole) }\end{array}$ & 96 & 100 & 100 \\
\hline 05 & Eskapar(piperazine) & 88 & 100 & 100 \\
\hline 06 & $\mathrm{t}$ - test & ** & $* *$ & $*$ \\
\hline
\end{tabular}

Table 2: Percent Non-Motile (Dead) $\mathrm{L}_{3}$ of Gastro Intestinal Nematode When Exposed To an Increasing Concentration of Aqueous Plant Extracts and Patent Drug in Vitro.

\begin{tabular}{|c|c|c|c|c|}
\hline $\begin{array}{l}\text { Sl. } \\
\text { No. }\end{array}$ & Name of the plant & $\begin{array}{l}\text { Percent } \mathrm{n} \\
\text { centration }\end{array}$ & $\begin{array}{l}\text { otile adult } \\
\text { lant extrac }\end{array}$ & $\begin{array}{l}\text { fferent con- } \\
\text { d patent drug }\end{array}$ \\
\hline 01 & Korolla & $\begin{array}{l}25 \mathrm{mg} / \mathrm{ml} \\
14\end{array}$ & $\begin{array}{l}50 \mathrm{mg} / \mathrm{ml} \\
35\end{array}$ & $\begin{array}{l}100 \mathrm{mg} / \mathrm{ml} \\
75\end{array}$ \\
\hline 02 & Neem & 11 & 25 & 45 \\
\hline 03 & Papaya seed & 30 & 45 & 73 \\
\hline 04 & $\begin{array}{l}\text { Eskanex } \\
\text { (levamisole) }\end{array}$ & 85 & 100 & 100 \\
\hline 05 & Eskapar(piperazine) & 93 & 100 & 100 \\
\hline 06 & $t$ - test & $*$ & * & $* *$ \\
\hline
\end{tabular}

\subsection{B. In vitro screening of ethanol extract}

The selected plants were also used for ethanol extract screening. The results obtained from this screening almost similar as in the case with aqueous extracts (table 2 and Table 3). However, ethanol extract were more effective against both adult and $\mathrm{L}_{3}$ stage even at a lower concentration level. All the selected plants were significantly effective against adults at $50 \mathrm{mg} / \mathrm{ml}$ concentration level (table 2). In case of $\mathrm{L}_{3}$ Korolla and papaya were significantly effective (table 3 ).

Table 3: Percent Non-Motile (Dead) Adult of Gastro Intestinal Nematode When Exposed To an Increasing Concentration of Ethanol Plant Extracts and Patent Drug in Vitro.

\begin{tabular}{|c|c|c|c|c|}
\hline \multirow[t]{2}{*}{$\begin{array}{l}\text { Sl. } \\
\text { No. }\end{array}$} & \multirow[t]{2}{*}{ Name of the plant } & \multicolumn{3}{|c|}{$\begin{array}{l}\text { Percent non-motile adult in different con- } \\
\text { centration of plant extracts and patent drug }\end{array}$} \\
\hline & & $10 \mathrm{mg} / \mathrm{ml}$ & $25 \mathrm{mg} / \mathrm{ml}$ & $50 \mathrm{mg} / \mathrm{ml}$ \\
\hline 01 & Korolla & 74 & 93 & 100 \\
\hline 02 & Neem & 69 & 94 & 100 \\
\hline 03 & Papaya seed & 84 & 98 & 100 \\
\hline 04 & $\begin{array}{l}\text { Eskanex } \\
\text { (levamisole) }\end{array}$ & 85 & 100 & 100 \\
\hline 05 & Eskapar(piperazine) & 93 & 100 & 100 \\
\hline 06 & $t$ - test & $* *$ & $* *$ & NS \\
\hline
\end{tabular}

Table 4: Percent Non-Motile (Dead) Adult Gastro Intestinal Nematode When Exposed To an Increasing Concentration of Ethanol Plant Extracts and Patent Drug in Vitro.

\begin{tabular}{|c|c|c|c|c|}
\hline \multirow[t]{2}{*}{$\begin{array}{l}\text { Sl. } \\
\text { No. }\end{array}$} & \multirow[t]{2}{*}{$\begin{array}{l}\text { Name of the } \\
\text { plant }\end{array}$} & \multicolumn{3}{|c|}{$\begin{array}{l}\text { Percent non-motile adult in different concentra- } \\
\text { tion of plant extracts and patent drug }\end{array}$} \\
\hline & & $10 \mathrm{mg} / \mathrm{ml}$ & $25 \mathrm{mg} / \mathrm{ml}$ & $50 \mathrm{mg} / \mathrm{ml}$ \\
\hline 01 & Korolla & 48 & 89 & 94 \\
\hline 02 & Neem & 63 & 92 & 97 \\
\hline 03 & Papaya seed & 71 & 93 & 100 \\
\hline 04 & $\begin{array}{l}\text { Eskanex } \\
\text { (levamisole) }\end{array}$ & 85 & 100 & 100 \\
\hline 05 & $\begin{array}{l}\text { Eskapar } \\
\text { (piperazine) }\end{array}$ & 93 & 100 & 100 \\
\hline 06 & t- test & $* *$ & $*$ & NS \\
\hline
\end{tabular}

Number of scientists reported the anthelmintic activity of neem against adult Ascaridia galli (Akhtar and Riffat, 1985; Ali, 2006) and other helminths (Akhtar and Riffat, 1984; Rahman, 2002; Hordegen et al., 2003; Sharma et al., 2003; Mishra et al., 2004; Githiori et al., 2004; Chandrawathani et al., 2006; Szewczuk et al., 2006). One of the active ingredients of neem leaves is Azadirectin which proved as an effective nematocidal compound (Sharma et al, 2003). Besides, neem leaves contain quercetin, a polyphenolic flavonoid, acts as anti-oxidant (Ghani, 2003) and vitamin C which also an anti-oxidant (Kayser, 2002). These antioxidant substances may inhibit the development and growth of adult nematode and larvae $\mathrm{L}_{3}$.

In this experiment, highest efficacy of papaya, neem leaves and korolla was found in $50 \mathrm{mg} / \mathrm{ml}$ ethanol extract $(100 \%)$ which is also found in patent drugs. These findings indicate that these plants have better efficacy on the inhibition and development adult nematode and its larvae $\mathrm{L}_{3}$. Rahman (2002) recorded the highest efficacy $(100 \%)$ of neem leaves in alcoholic extract whereas aqueous extract have the lower efficacy (92\%) than alcohol against gastrointestinal nematodes in goats. Akhter and Riffat (1985) proved the highest efficacy $(67.8 \pm 4.6$ reduced EPG) of neem seeds in ethanol extract followed by methanol $(18.5 \pm 1.8)$ and water extract $(15.7 \pm 4.3)$ in Ascaridia galli infected chickens in vivo. Kumar et al. (2007) stated that contents of the alcoholic extract are different from aqueous extract and contain substances which have better anthelmintic effect. Papaya showed its anthelmintic efficacy against Ascaridia galli for many times. Different parts of papaya tree proved effective against development of infective larvae of Ascaridia galli (Purwati and He, 1991) and against adult Ascaridia galli (Lal et al., 1976; Satyanarayana and Krishnaiah, 1982; Purwati and He, 1991; Mursof and He, 1991; Singh and Nagaich, 1999; Sarija et al., 2001; Adu and Akingboye, 2002; Ali, 2006). Papaya also found as an anthelmintic against other helminths (Satrija et al,, 1994; Murdiati et al., 1997; Lamtiur, 2000; Fajimi et al., 2001; Rahman, 2002) rather than Ascaridia galli. The anthelmintic efficacy of papaya might be due to presence of proteolytic enzymes such as papain, chymopapain and lysozymes in the latex as well as in leaves (Dakpogan, 2005). All parasites and their developmental stages of course the protein substance that can be ingested by papain Kumar et al. (1991) compared in vitro effects of BITC (benzylisothiocyanate), an anthelmintic principle of Carica papaya with mebendazole against Ascaridia galli and found effective.

In both (aqueous and ethanol) cases of in vitro screening adults showed structural alterations. Grossly the extracts caused inhibition of spontaneous motility of worm, this was characterized by initial, short lasting, and small increases in amplitude and tone of contractions followed by paralysis. The findings also substantiated by Tandon et al. (1997) and Bishnu pada et al. (1997) reported that scanning electron microscopy (which was not performed in this study) of parasites exposed to plant extracts (Flemingia vestita, Cannabis sativa) revealed structural alteration in the integument/surface architecture particularly of the papillated surface. Deep scars were also observed on the dorsal and ventral surface. It was observed in the present study that in all cases, the complete cessation of motility and mortality of worm and larvae depends on the type and concentration of the extracts used. The time for complete cessation of motility and mortality was found to be reduced as the concentrations of the extracts increased. This observation gave the indication that mortality percentage varied significantly among the plants, solvents and doses. In this study PBS was used for incubation of adult and infective larvae containing plant extract but test may be more reliable if it is possible to incubating the adult and infective larvae in abomasal or rumen fluid containing plant extract which was described by Molan et al. (2000).

\section{Conclusion}

The anthelmintic effect of some medicinal plant materials such as neem leaves, neem seeds, papaya seeds, korolla (whole) and modern anthelmintic were studied preparing their aqueous and ethanol extract by giving in vitro trial on adult nematode and developmen- 
tal stage larvae $\left(\mathrm{L}_{3}\right)$ of fowl. However, further studies are recommended with developmental stages of other helminth parasites of poultry both for the plants found to be effective and those found to be inactive against the development of larvae $\left(\mathrm{L}_{3}\right)$ in order to determine the spectrum of activity of the former and possible action against other helminth with the latter.

\section{References}

[1] Adu OA and Akingboye KA, 2002. Anthelmintic efficacy of Pawpaw (Carica papaya) latex in Peacock. 7th Annual Conference of Anima Science Association of Nigeria (ASAN), held at September, 16-19, 2002, Nigeria.

[2] Akhtar MS and Riffat S, 1985. Evaluation of Melia azedarach Linn. Seeds (Bakain) and piperazine against Ascaridia galli infection in chickens. Pakistan Veterinary Journal, 5: 34-37.

[3] Akhter MS and Riffat 5, 1984. Efficacy of Melia azedarach Linn. And morantal against naturally acquired gastro intestinal nematodes in goats. Pakistan Veterinary Journal, 4: 176-179.

[4] Ali MA, 2006. In Vitro anthelmintic effects of some indigenous plants against Ascaridia galli of indigenous chikens, MS thesis. Submitted to the Department of Parasitology, Bangladesh Agricultural University, and Mymensingh. pp 44.

[5] Begum, T. 1997. Comparative efficacy of some indigenous plants (Bironja, Turmeric and Veranda) with that of patent drug Nilzan against trematodiasis and nematodiasis in sheep. M. S. in Pharmacology, A Thesis Submitted to the Department of Pharmacology, Bangladesh Agricultural University, and Mymensingh.

[6] Bishnupada $\mathrm{R}, \mathrm{V}$ Tandon, $\mathrm{B}$ Roy and $\mathrm{V}$ Tandon, 1997. In vitro fluckicidal effect of leaf extract of Cannabis sativa on the trematode of Fasciola buska. Indian J Exp Biol, 35(1): 80-82.

[7] Chandrawathani P, Chang KW, Nurulaini R, Wailer PJ, Adnan M, Zaini CM, Jamnah 0, Khadijah S and Vincent N, 2006. Daily feeding of fresh Neem leaves (Azadirachta indica) for worm control in sheep. International Journal of Oncology, 29(5): 1269-1278.

[8] Dakpogan HB, 2005. Free range chick survivability in improved conditions and the effects of three medicinal plants on Eimeria tenella. M.Sc. Thesis, Department of Veterinary Pathobiology, the Royal Veterinary University, Denmark.

[9] Fajimi AK, Taiwo AA, Ayodeji IO, Adebowale EA and Ogundola FI 2001. Therapeutic trials on gastrointestinal helminth parasite of goats using pawpaw seeds as a drench. Proceedings of the international conference on sustainable crop. Livestock production for i livelihoods and natural research Management. West Africa held at the International Livestock Research Institute (ILRI) in partnership with International Institute of Tropical Agriculture between Nov. 9-23.

[10]Ghani, A. 2003. Medicinal plants of Bangladesh with chemical constituents and uses. $2^{\text {nd }}$ edn. Asiatic Society of Bangladesh, Dhaka, Bangladesh, pp. 100- 355.

[11]Githiori JB, Hoglund J, Wailer PJ, Leyden and Baker R, 2004. Evaluation of anthelmintic properties of extracts from some plants used as livestock dewormers by pastoralist and smallholder farmers in Kenya against Heligmosomoides polygyrus infections in mice. Journal of Ethnopharmacology, 90(1): 167-170.

[12]Hördegen P, Hertzberg H, Heilmann J, Langhans W and Maurer V, 2003. The anthelmintic efficacy of five plant products against gastrointestinal trichostrongylids in artificially infected lambs, Veterinary Parasitology, 117(1-2): 51-60.

[13]Kumar VH, Ganapath S, Rizvi W and Hemamalini K, 2007. In vitro antifilarial potential of the leaf extracts of Ficus infectoria ROXB on cattle parasite Seteria cervi. Pharmacologyonline 2: 266-276

[14]Kumar, D., Mishra, S. K. Tripathi, H. C. 1991. Mechanism anthelmintic action of benzylisothiocyanate. Fitoterapia. 62(5): 403-410.

[15]Lal, J. Chandra, and Sabir, M. 1976. In vitro anthelmintic of some indigenous medicinal plans on Ascaridia galli worms. Indian Journal of Physiology and Pharmacology. 20: 64.

[16]Lamtiur L, 2000. Uji Aktivitas Anthelmintik Infus Biji Pepaya (Carica papaya L.) terhadap Mencit Putih (Mus musculus L.) Galur Swiss yang Terinfeksi Cacing Hymenolepis nana. Skripsi. Fakultas Farmasi Universitas 17 Agustus 1945. Jakarta.

[17]Mishra V, Parveen N, Singhal KC and Khan NU, 2004. Antifilarial activity of Azadirachta indica on cattle filarial parasite Setaria cervi. Medical and Vetetrinary Entomology, 18(4):449-452.

[18]Molan AL, Waghorn GC, Min BR, McNabb WC, 2000. The effect of condensed tannins from seven herbages on Trichostrongylus colubriformis larval migration in vitro. Folia Parasitologica 47, 39-44.

[19]Mostofa, M. 1983. Efficacy of some indigenous medicinal plants against gastro intestinal nematodiasis in cattle and their comparative activity with that of nemafax. M. Sc. (Vet. Sci.), A Thesis Submitted to the Department of Pharmacology, Bangladesh Agricultural University, Mymensingh.

[20]Murdiati TB, Beriajaya \& Adiwinata G, 1997. Aktivitas getah pepaya terhadap cacing Haemonchus contortus pada domba. Majalah Parasitologi Indonesia, 10: 1-7.

[21]Mursof EP and He S, 1991. A potential role of papaya latex as an anthelmintic against patent Ascaridia galli infection in chicken. Hemera Zoa, 74: 11-20.

[22]Purwati E and He S, 1991. A potential role of Papaya latex as an anthelmintic against Ascaridia galli infection in chicken. Hemara Zoa, 74: 1-5.

[23] Rahman M, 2002. In vitro and in vivo anthelmintic effects of some plants against gastrointestinal nematodes of goats. MS thesis, submitted to the Department of Parasitology, Bangladesh Agricultural University, Mymensingh. May, 2002. pp 108.

[24] Satrija F, Retnani EB, Ridwan Y and Tiuria R, 2001. Potential use of herbal anthelmintics as alternative antiparasitic drugs for small holder farms in developing countries. Livestock Community and Environment. Proceedings of the $10^{\text {th }}$ Conference of the Association of Institutions for Tropical Veterinary Medicine, Copenhagen, Denmark, 2001.

[25] Satyanarayana-Rao V and Krishnaiah KS, 1982. In vivo effects of aqueous extract of seed of Carica papaya against Ascaridia galli in experimentally infected chicks. Indian Journal of Animal Sciences, 52(6): 485-486.

[26] Sharma V, Walia S. Kumar J, Nair MG and Parmar BS, 2003. An efficient method for the purification and characterization of nematicidal azadirachtins $\mathrm{A}, \mathrm{B}$, and $\mathrm{H}$, using MPLC and ESIMS. Journal of Plant Physiology, 160(5):557-564

[27]Singh K and Nagaich S, 1999. Efficacy of aqueous seed extract of Carica papaya against common poultry worms Ascaridia galli and Heterakis gallinarum. Journal of Parasitic Diseases, 23(2): 113-116.

[28]Szewczuk VD, Mongelli ER and Pomilio AB, 2006. In vitro anthelmintic activity of Melia azadirach naturalized in Argentina. National Library of medicine, US.

[29]Tandon V, Pal P, Roy B, Rao HSP, Reddy KS, 1997. In vitro anthelmintic activity of root tuber extract of Flemingia vestita, an indigenous plant in Shillong, India. Parasitol Res. 83:492-498. 